\title{
Pondering over the Problems of Immaterial Assets
}

\author{
Hu Miaozhong \\ Zhejiang Agricultural Business Vocational colleg \\ shaoxing, Zhejiang, China \\ hmzsxhmzsx@yahoo.com.cn
}

\begin{abstract}
The intangible assets have become an important driving force of national economic growth and enterprise development with the transition from industrial age to the information age. People become more concerned about the intangible assets. While, the current criteria have some problems in accounting treatment, such as unreasonable confirming and amortizing intangible assets. This paper puts forward some measures to improve the confirmation and amortization of intangible assets.
\end{abstract}

Keywords- immaterial assets; national economic accounting treatment;

\section{INTRODUCTION}

In today's world, the knowledge productivity has become the primary and key factor of economic development. Intangible assets have increasingly become the main motivation which can decide the enterprise cash flow and the market value in the future. With the development of the economic, the former phenomenon that the tangible assets are valued and the intangible assets are despised is changed. Especially in recent years, the government passed some accounting regulations of intangible assets which complied with the trend of the times. To an extent, it improves the qualities of the intangible assets accounting and information disclosure. Because the new situations and problems were not taken into full account in the formulation and revision of regulations, it has some shortages.

\section{Problems In InTANGIBLE Assets Standards}

\section{A. The Irrationality of Intangible Assets Confirmation}

The identifiable standards are already specified in the intangible asset standards. An asset, which satisfies any of the following conditions, shall meet the identifiable standards as mentioned in the definition of intangible assets. (1) Intangible assets can be separated or divided out from the enterprise. And they can be used to sell, transfer, grant permission, lease or exchange alone or with related contracts, assets or liabilities. (2) They derive from the contractual rights or other legal rights, no matter whether these rights could be transfer or separated from the enterprise or other rights and obligations. The 11th stipulation: the internally generated goodwill, brand names and newspapers internally generated could not be recognized as intangible assets. It can be seen that the enterprise accounting standards emphasize the identifiability of intangible assets. The internally generated goodwill, brand name, newspapers are removed because they could not be identified. It does not clear and definite the details of intangible assets, which make a lot of important intangible be foreclosed. This makes the whole valuation of enterprise be underestimated. What's more, the market economy in our country is still not perfect and the enterprise consciousness does not reach the designated position. So some enterprise cannot correctly measure the values of intangible assets and it makes the reflections of accounting information seriously distort.

\section{B. The unreasonable valuation methods of self-developed intangible asset}

The intangible assets standards provide that the cost of self-developed intangible asset includes the total outlay from the asset satisfied the conditions of intangible assets to achieve the intended purpose, but the expenditures expenses of prior periods do not need to be adjusted. We think the valuation methods have the drawback of that it does not reflect the real value of intangible assets. The development costs of some patents and trademark right are very high, so the book value and the actual price difference when priced in actual costs. Because of the uncertainty in development and design process of self-developed intangible assets, it can make excess profits after the development process. And the cost of self development is below itself value. Sometime the cost is very little and the value is very high. For example, the value of trademark right, "Guizhou Maotai” was evaluated as 13.957 billion yuan, "Wahaha" was evaluated as 4.918 billion, and "Metersbonwe" was evaluated as 1.287 billion yuan. The values of those trademark rights are far from the costs. It is hard to supply more related information to users, by using the costs replace the values to reflect the special assets in the account.

\section{The indistinguishable intangible assets in development phase}

The intangible assets develop within the enterprise is segmented into research phase and development phase. The expense in research phase is accounted into current profit, and the expense in development phase is capitalized if certain conditions are met. The article 7 in the guidelines said that, the research phase is a promethean planned investigation to acquire and comprehend new scientific or technological knowledge. The development phase is to apply the research result and other knowledge to a plan or design and to produce new and substantially improved material, equipment and product before the commercial production and use. But in practice, due to the business complexity and high risk of intangible assets in research and development phase, it wiil bring casualness and uncertainty to divide research cost and development cost according to research phase and development phase, and the enterprise will have 
major working place. But it is hard to distinguish research phase and development phase in operation, not to mention to the accountant who is not very proficient in science and technology.

At the same time, counted the research cost into the current profit or loss and development expenditure capitalization is conducive to increase technology innovation and improve the enthusiasm of the enterprise technological innovation, which provides some enterprises opportunities to control profits. The increase of the expenses is bound to be a cause of the decrease of the profit of the period, when the research and development expenditure are treated as cost business accounting. The administrator would not dissatisfy investors with the decrease of outstanding achievement, and they also do not want the phenomenon that the predecessors trees descendants cool. So they confirm the expenses in development stage as intangible assets with a series of documents. Although this method makes for good short-term profit, the long-term interests of enterprise development would be harmed. Research and development activities is huge uncertainty, it still has the possibility of failure when it was proved to meet the condition of capitalization in development stage. There is a certain risk for capitalization.

\section{The Irrationality of Intangible Assets amortization}

Intangible assets standards divide intangible assets into two kinds, certain service life and uncertain service life. If the service life is limited, the enterprise should estimate the service life. The amortization method of the way of duly realizing economic interests which is related to the intangible assets should be chosen. If the service life is uncertain, it could be amortized. However, impairment tests should be carried out in each accounting period. The original criterion is amortised using the straight-line method, while this provision fully embodies the conservatism principle. It makes the accounting information is more accord with the requirements of the accounting information quality and more objective. When the service life of intangible assets is certain, the criterion does not definite the method and useful life of amortization. In addition, the rules of re-checking and regulation of the intangible assets which are limited in service life are not sufficient at the end of a year. The possibility of adjusting surplus when the enterprises adjust the accounting methods increases.

\section{THOUGHT OF THE PROBLEMS OF SOME INTANGIBLE ASSETS STANDARDS}

\section{A. Solve some problems about identifying intangible assets with enumerated method.}

Intangible assets standard in our country to the definition of intangible assets is especially emphasized its identifiability, which makes achieving goodwill, brand and name of the press outside of the range. Although they are enterprise assets, neither belong to the fixed assets nor to the intangible assets. Then which kind should they belong to? Take goodwill for example, this kind of invisible wealth has been more and more recognized and accepted. People are aware of the importance and the value it contains and they are willing to spend more money and energy to build it. However, in the criterion, only in the consolidated financial statements involves a little. Currently, intellectual products, such as knowledge and skills, are unable to reflect in the balance sheet. The recessive value of this vacant badly needs specifying by intangible assets standard or a separate accounting standard. In addition, because of factors like long-term influence of the old standards, some enterprises have turned a blind eye to the intangible assets, even if some enterprise realize these resources value, actual confirmation and its value cannot be measured. The author thinks it is convenient for the enterprise financial personnel to confirm intangible assets by using the international accounting practices to list intangible assets in current economic environment, such as patent, copyright, trademark, computer software, Internet domain name, etc.

\section{B. The improvement of amortization of intangible assets}

1) The reasonableness appliance of the straight-line method and accelerated amortization method

Internationally, the amortization of intangible assets mainly adopts linear method. Although intangible assets standards in our country specifies that amortization of intangible assets should reflect the expected consumption of the intangible assets produced by the way of future economic benefits, instructions and guidance for specific amortization life and method are not given. The author thinks that intangible assets with limited life, including land use rights and patent, whose expected useful life is specified and impairment risk is lower, should be amortized by linear method. For the rapidly updated intangible assets of the science and technology, such as electronic production enterprises which has an important status in China's national economy and develops faster, ship industry enterprises, the production of "machine tool" which trains the mechanical enterprise, aircraft manufacturing enterprise, automobile manufacturing enterprise, chemical manufacturing enterprises and pharmaceutical production enterprise and other special industry, the amortization of it can use accelerated amortization method which is similar to fixed assets accelerated depreciation method. This can take investment as soon as possible, also accord with the accounting of the principle of caution. Accelerated amortization method refers to a method that the intangible assets will be amortized according to the principle of less than first after sharing in every amortization period and the burden of amortized decrease year by year. Withdrawal amortize debits "management cost" course, "other business cost" course etc., credited "accumulative amortization".

For example, a company purchased an intangible asset, and the price was 1 million Yuan. The service life of the intangible assets is estimated as 5 years. The net residual value of the intangible asset is assumed as zero and is amortized according to the sum of the yeas digits. The amortization of every year is shown in the table below:

Because the intangible assets with uncertain service lives such as trademark, trade name, etc. will gradually appreciate in the course of production and operation, it needs not to be amortized. 


\section{2) The reasonable application of amortization}

Intangible assets standards require that the service life and amortization method of the intangible assets with limited service life should be checked at the end of year. The amortization period and method of the intangible assets should be altered when they are different with the previous estimates. On the other hand, these standards may make enterprise could change their accounting estimates, and they have large selectivity. When the enterprise re-check the service life of intangible assets, if the elements which affect the service life in the previous year changed, and the enterprise can't estimate that. The enterprise cannot reasonable expect the change, it can be taken as a kind of changes in accounting estimates, otherwise, it should be treated as previous accounting errors to adjusting retrospectively.

From the period of amortization, the intangible assets of our country do not stipulate the specific amortize fixed number of year, and it only stipulate the intangible assets

\begin{tabular}{c|c|c|c|c}
\hline Year & Service Year & $\begin{array}{c}\text { Original price - net } \\
\text { production } \\
\text { value }\end{array}$ & $\begin{array}{c}\text { Years amortization } \\
\text { rate }\end{array}$ & Years amortized \\
\hline The 1st year & 5 & 100 & $5 / 15$ & 33.33 \\
The 2nd year & 4 & 100 & $3 / 15$ & 26.67 \\
The 3rd year & 3 & 100 & 20 & 13.33 \\
The 4th year & 2 & 100 & $1 / 15$ & 6.67 \\
The 5th year & 1 & 100 & 15 \\
\hline
\end{tabular}

\section{The attention on burgeoning intangible assets}

For now, the study on intangible assets in our country still remains on traditional intangible assets (such as patent right, proprietary technology, trademark right, copyright, proprietary right, goodwill etc.), but there are less scholars of our country to research some burgeoning intangible assets such as intellectual capital, knowledge capital and the core competence of enterprise. In 2004, on the ownership competition of CCTV advertisement, the Procter\&Gamble Company got the "Brand Kings" with .385 billion and became the first international "Brand Kings". More remarkable still, other company in competition for the brand given out on some other international business such as Unilever, Colgate, NEC, Toyota, KFC, TSKF. The competition of the "Brand Kings", in effect, is the contest among traditional intangible asset. The establishment should pay high attention to traditional intangible asset and at the same time develop the invisible intangible assets such as knowledge resource of business enterprise, the ability of enterprise management level, the organization chart of enterprise strategy and culture and the external value chain so that the establishment can integrate the core deposit intangibles and enhance the competitiveness.

\section{CONCLUSIONS}

The influences of the implementation of the intangible assets standards are profound and significant. They improve the quality of accounting information and company performance and promote the healthy and orderly with a limited service life that it can be amortized in the service life. Intangible assets with uncertain service life may not be amortized. However there is an assumption, the service life of the intangible assets is 20 years at most from the date of availability. Only in a few cases there are some convincing evidences the service life can be longer than 20 with long service life should be estimated every year to determine whether impairment charge happens. The amortization life and the amortization method also should be inspected at year end. If the years of estimated useful life of fixed assets vary widely with the prior estimate, the amortization mode and the amount need corresponding adjustments. It is clear that the provisions of the international accounting standards are more concrete and scientific to the amortization life. We should refer to the international accounting standards. years. At the same time, international standards also stipulates: the recoverable amount of the intangible assets

development of China's capital market and the entire market economy. However, the actual operational level has shortage that still needs timely specific solutions and instructions of the relevant departments according to the standards. The regulation of relevant departments and the quality of accounting information should be improved. At the same time, the accountants need professional training, and the accountants' abilities in professional judgments need be improved. In addition, we still should improve the assessment, evaluation and supervision system to ensure the implementation of intangible assets standards.

\section{REFERENCES}

[1] Ministry of Finance Accounting Standards for Business Enterprises No. 6 - Intangible assets [S] Economic Science Press, 2006.

[2] China Accounting Standards Committee translated the International Accounting Standards (2002) [M]. Beijing: China Financial and Economic Publishing House, 2003. [3] Ning Xiangbo. Intangible Assets Accounting Standards Interpretation[J]. ACCOUNTING, 2007(2):83-84 [4] Liu Shengqiang intangible assets accounting question [J]. China township enterprises accounting, 2007 ( 5): 16

[5] JiangYufang. Intangible Assets accounting treatment under the new standards of thinking [J]. Business Accounting, the second half of 2007 (1) :30-31

[6] Ramirez, P.G. ; Hachiya, T. Intangible assets and market value of Japanese industries and firms [J]. International Journal of Technology Management, 2012, 59(1/2)

[7] Jan-Philipp Kramer ; Elisabetta Marinelli ; Simona Iammarino ; Javier Revilla Diez. Intangible assets as drivers of innovation: Empirical evidence on multinational enterprises in German and UK regional systems of innovation [J]. Technovation, 2011, 31(9) 